\title{
Cloning, Bioinformatics and Activity Analysis of the $M n h B$ Gene from the Moderately Halophilic Bacterium Halobacillus Y5
}

\author{
Wang Yongjie ${ }^{1}$, Liu Haoran ${ }^{1}$, Zhang Guannan ${ }^{1}$, Zhu Lingli ${ }^{1}$, Yuan Shuai ${ }^{1}$, Wang Yanhong ${ }^{1,2^{*}}$
}

${ }^{1}$ College of Life Science and Technology, Heilongjiang Bayi Agricultural University

${ }^{2}$ Heilongjiang Provincial Key Laboratory of Environmental Microbiology and Recycling of Argo-Waste in Cold Region, College of Life Science and Biotechnology, Heilongjiang Bayi Agricultural University, Daqing, 163319, PR China

DOI: $10.36347 /$ sjet.2021.v09i04.001

| Received: 19.02.2021 | Accepted: 10.04.2021 | Published: 15.04.2021

*Corresponding author: Wang Yanhong

Abstract

Original Research Article

Objective: The mnhB gene of Halobacillus Y5 was cloned to clarify its basic biological information. Methods: The genome of Halobacillus Y5 was extracted and the gene fragments were obtained by PCR, then 400 900 bp fragments were recovered and linked to vector pUC18. The constructed recombinant plasmids were transformed to competent E.coli KNabc by functional complementation, and the strain containing the gene of $\mathrm{Na}^{+} / \mathrm{H}^{+}$antiporters was screened for bioinformatics analysis. The positive monoclonal strains were screened by specific medium. Results: $m n h B$ gene has two CDS regions, respectively $305 \mathrm{bp}$ and $128 \mathrm{bp}$, encoding 96 amino acids. The predicted relative molecular weight is $11048.16 \mathrm{Dt}$, the isoelectric point is 4.66 , the fat coefficient is 130.40 , and the instability coefficient is 29.15 . It is a stable protein with a half-life of $30 \mathrm{~h}$. Comparison of similarity between mnhB from Halobacillus Y5 and 5 sequences, the homology of wp_101843976.1, wp_082234107.1, wp_079529991.1, wp_128522668.1, wp_08502981.1 were $93 \%, 69 \%, 78 \%, 69 \%, 67 \%$, respectively. Through phylogenetic tree analysis, the $\mathrm{Na}^{+} / \mathrm{H}^{+}$ antiporters from Halobacillus Y5 is in a separate branch, which may be a new member of $\mathrm{Na}^{+} / \mathrm{H}^{+}$antiporter. $\mathrm{Na}^{+}\left(\mathrm{Li}^{+}\right.$, $\mathrm{K}) / \mathrm{H}^{+}$antiport activity was detected from everted membrane vesicles prepared from $E$. coli /pUC- mnhB but not those of /pUC18. Conclusion: A new $m n h B$ gene was successfully cloned, which laid a theoretical foundation for the development and utilization of Halobacillus Y5.

Keywords: Moderately halophilic bacterium; $m n h B$ gene; $\mathrm{Na}^{+} / \mathrm{H}^{+}$antiporter; Membrane proteins; Cloning; Bioinformatics analysis.

Copyright $\odot 2021$ The Author(s): This is an open-access article distributed under the terms of the Creative Commons Attribution 4.0 International License (CC BY-NC 4.0) which permits unrestricted use, distribution, and reproduction in any medium for non-commercial use provided the original author and source are credited.

\section{INTRODUCTION}

High concentration of $\mathrm{Na}^{+}$will have a huge toxic effect on the growth, reproduction and development of microorganisms and other life activities.Inorder to adapt to this poisoning, microorganisms have formed two salt-appropriate mechanisms: [1] Internal salt strategy: The microorganisms accumulate high concentrations of $\mathrm{NaCl}$ as an osmotic agent to maintain the osmotic balance of the microorganisms. At present, this mechanism is only found in some aerobic archaea and a few extremely halophilic aerobic bacteria [2]. Salt rejection strategy. Most halophilic and salt-tolerant microorganisms use this strategy to resist the high-salt environment to maintain their normal growth. Under the hypertonic conditions of this kind of microorganisms that use salt rejection strategies to resist high salt stress, on the one hand, organic compatible solutes are accumulated in the body to adjust the osmotic balance inside and outside the cell; on the other hand, excess $\mathrm{Na}^{+}$in the cellare expelled from the cell outside [1]. In this study, we first cloned the $m n h B$ gene, and then used the functional complementation method to transform the ligation product into the defective E. coli KNabc competent cells, inoculated in a high-saline medium, and speculated that the $\mathrm{Na}^{+} / \mathrm{H}^{+}$reverse of the $m n h B$ gene transport function, this study laid a theoretical foundation for the development and utilization of the moderately halophilic bacterium Halobacillus Y5.

\section{MATERIALS AND METHODS Strains and plasmids}

Escherichia coli KNabc (Dnha A, Anha B, $\triangle c h a A)$ and plasmids pET19 (b), pUC18 were provided by the Microbiology Laboratory of Northeast Agricultural University, moderately halophilic bacteria Halobacillus Y5, negative control bacteria BL21/pET19 (plasmid pET19 is chemically transformed into the large intestine Escherichia BL21) and Escherichia coli 
BL21 were provided by the Bioengineering Laboratory of Heilongjiang Bayi Agricultural University.

\section{Main reagents}

Hind III and EcoR I, $1 \mathrm{~Kb}$ DNA Ladder Marker, and T4 DNA ligase were purchased from Bao Bioengineering (Dalian, China) Co., Ltd.; Omega gel recovery kit was purchased from Harbin Shiguo Biotechnology Co., Ltd., and other reagents were of analytical grade.

\section{Medium}

LB medium and LBK medium ${ }^{[2]}$ : The extraction of Halobacillus Y5 genomic DNA is activated with LB medium, the specific steps are: $1 \%$ inoculum is inoculated into $500 \mathrm{~mL} \mathrm{LB}$ medium, $37^{\circ} \mathrm{C}$, $16800 \times g$ culture $16 \sim 18 \mathrm{~h}$; centrifuge at $9600 \times \mathrm{g}$ for 5 min at $4^{\circ} \mathrm{C}$, collect the bacteria, and wash the bacteria with sterile water. The total genome was extracted and stored at $-20^{\circ} \mathrm{C}$ after electrophoresis [3].

\section{Amplification of $m n h B$ transporter gene}

Premier 5.0 was used to design primers [4], $m n h B$ transporter gene $\mathrm{F}$ primer sequence: $5^{\prime}$ CCGGAATTCTGGTCGTATCGTTACAATAG-3' (the underlined part is EcoRI restriction site), $\mathrm{R}$ primer sequence: $\quad 5$-CCCAAGCTTTTAATGATGA TGATGATGAT GATG-3' (The underlined part is the Hind III restriction site). The primers were synthesized by BGI (Beijing) Biotechnology Co., Ltd. The fragments of 400 900 bp were recovered by gel and ligated with Hind III and EcoR I fully digested pUC18 vector to construct recombinants. The ligated vector and target fragments were electro-transformed into EP432 competent cells [5], and coated Inasolid LBK medium with a $\mathrm{Na}^{+}$concentration of $0.5 \mathrm{~mol} / \mathrm{L}$ and $50 \mu \mathrm{g} / \mathrm{mL}$ Amp, cultured at $37^{\circ} \mathrm{C}$ for $24 \mathrm{~h}$ to select positive clones.

\section{Bioinformatics Analysis}

DNAMAN biological software for open reading frame (ORF), amino acid sequence analysis and nucleic acid alignment; use BLAST in the NCBI website for nucleic acid and amino acid sequence homology analysis; use the website http://web.expasy.org/protparam/Perform protein relative molecular mass and theoretical isoelectric point analysis; use http://www.cbs.dtu.dk/services/TMHMM/ to predict the transmembrane structure of protein sequences; apply http://web.expasy. org/protscale/ for hydrophobicity analysis; MEGA is used 5.0 software, select the Neighbor-Joining method to construct a phylogenetic tree; use the website https://swissmodel.expasy.org/ to simulate the threedimensional structure of $m n h B$ and related sequences to analyze the structural similarity.

\section{Assay of $\mathrm{Na}^{+}\left(\mathrm{Li}^{+}\right) / \mathrm{H}^{+}$antiport activity}

The $\mathrm{Na}^{+}\left(\mathrm{Li}^{+}, \mathrm{K}\right) / \mathrm{H}^{+}$antiport activity of everted membrane vesicles was determined according to the extent of the collapse of a transmembrane proton gradient, with acridine orange as the $\mathrm{pH}$ indicator, as described by Rosen [6]. Fluorescence was monitored with a Hitachi F-4500 fluorescence spectrophotometer (Hitachi Ltd, Tokyo, Japan) at excitation and emission wavelengths of 495 and $530 \mathrm{~nm}$, respectively.

\section{RESULTS AND ANALYSIS \\ Sequence analysis of $m n h B$ gene of Bacillus halophilus}

PCR fragments by agarose gel electrophoresis to check the size of the amplified gene $m n h B$. The results showed that its length was between 400 and 900 bp, which were in line with the expected length of 433 bp, and the length of the fragment was recovered by the gel $[6,7]$. Import the sequencing result to the vector sequence into DNAMAN software. After comparing them, it was found to have $97 \%$ homology with the MSMB of Halobacillus sp. Marseille-P3879. Then use NCBI's online ORF program to determine its CDS region, its ORF1 is $305 \mathrm{bp}$, ORF2 is $128 \mathrm{bp}$, a total of 96 amino acids are encoded in Table 1. Compare the similarity of $m n h B$ from Halobacillus Y5 with 5 related sequences. The results of the comparison are shown in the figure below. It is with login WP_ 101843976.1 . WP_ 082234107.1、WP_ 079529999.1、WP 128522668.1、WP_ The homology of 085029880.1 protein was $93 \%, 69 \%, 78 \%, 69 \%, 67 \%$, respectively (Fig. 1).

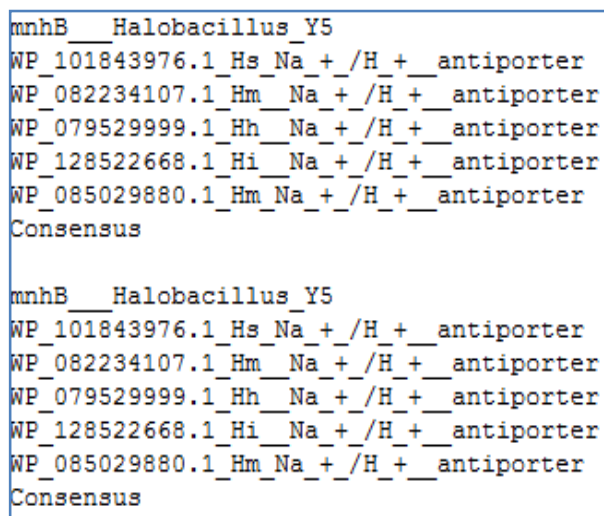

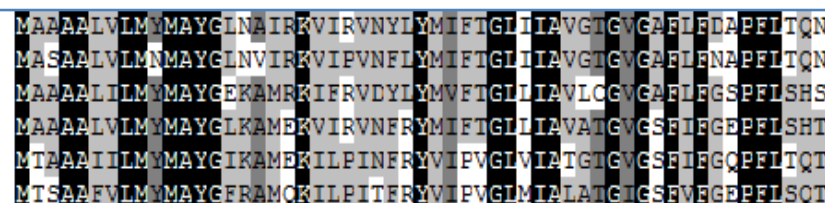

maaalvlmymayglkamrkipvnflymiftgl iavgtgvgaflfg pflsqt

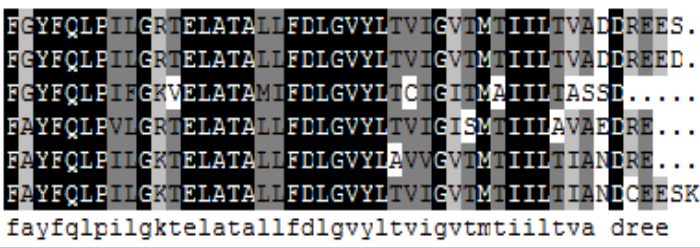

fayfqlpilgktelatallflgvyltvigvtmtiltva dree

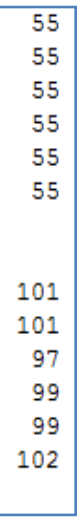

Fig-1: Alignment of $m n h B$ with associated $\mathrm{Na}^{+} / \mathrm{H}^{+}$antiporters 


\section{Analysis of physical and chemical properties of protein \\ mnhB protein was composed of 96 amino} acids, of which Leu and ALA were $14.9 \%$ and $11.9 \%$ respectively (Table 1). The isoelectric point was 4.66 , the negatively charged amino acid residue number $\left(\mathrm{ASP}^{+} \mathrm{clu}\right)$ was 5 , the positively charged amino acid residue number $\left(\mathrm{Arg}^{+} \mathrm{clu}\right)$ was 7 , and the whole protein was negatively charged. The protein molecular formula is c517h813o137n119s5, fat coefficient is 130.40 , instability coefficient is 29.15 , extinction coefficient is 0.809 , half-life is $30 \mathrm{~h}$. 994, which is a hydrophobic protein (Fig. 2).

Table-1: Amino acid composition of $\mathbf{m n h B}$

\begin{tabular}{|l|l|l|l|l|l|}
\hline Amino acid & Amount & Percentage (\%) & Amino acid & Amount & Percentage (\%) \\
\hline Ala (A) & 12 & 11.9 & Arg (R) & 4 & 4 \\
\hline Asn (N) & 3 & 3 & Asp (D) & 4 & 4 \\
\hline Cys (C) & 0 & 0 & Gln (Q) & 2 & 2 \\
\hline Glu (E) & 3 & 3 & Gly (G) & 9 & 8.9 \\
\hline His (H) & 0 & 0 & Ile (I) & 9 & 8.9 \\
\hline Leu (L) & 15 & 14.9 & Lys (K) & 1 & 1 \\
\hline Met (M) & 5 & 5 & Phe (F) & 7 & 6.9 \\
\hline Pro (P) & 2 & 2 & Ser (S) & 1 & 1 \\
\hline Thr (T) & 9 & 8.9 & Trp (W) & 0 & 0 \\
\hline Tyr (Y) & 6 & 5.9 & Val (V) & 9 & 8.9 \\
\hline
\end{tabular}

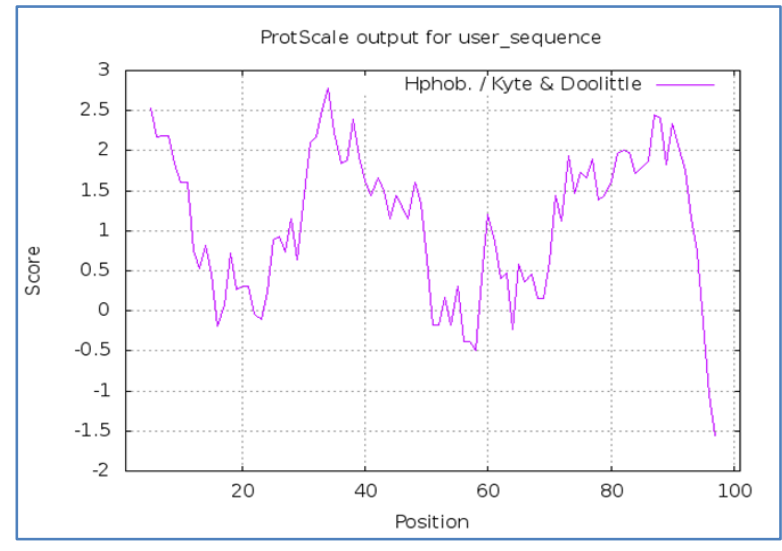

Fig-2: Analysis of hydrophobicity of $\mathrm{mnhB}$

\section{Protein cell localization and structure prediction}

DNMAN software analysis showed that the length of the foreign DNA fragment of the recombinant plasmid was $433 \mathrm{bp}$, which contained two possible
ORF1 and ORF2. It was predicted that 305 amino acids related to cation reverse transporter and 128 amino acids related to $\mathrm{H}^{+}$/ cation transporter were encoded respectively. It was preliminarily speculated that the protein was a membrane protein. Utilize http://www.cbs.dtu.dk/services/TMHMM/

Topoisomeric analysis of ORF2 protein showed that there were two transmembrane domains (Fig. 3), indicating that ORF2 protein was a transmembrane protein located in the cell membrane. Using the website https://swissmodel.expasy.org/ $m n h B$ gene and its five related sequences (accession No_ 101843976.1、WP 082234107.1、WP_079529999.1、WP_ 128522668.1 、WP_ 085029880.1). The results showed that the three-dimensional structures of the six proteins were very similar (Fig. 4). It is speculated that $m n h B$ gene may have the function of sodium / hydrogen ion reverse transport.

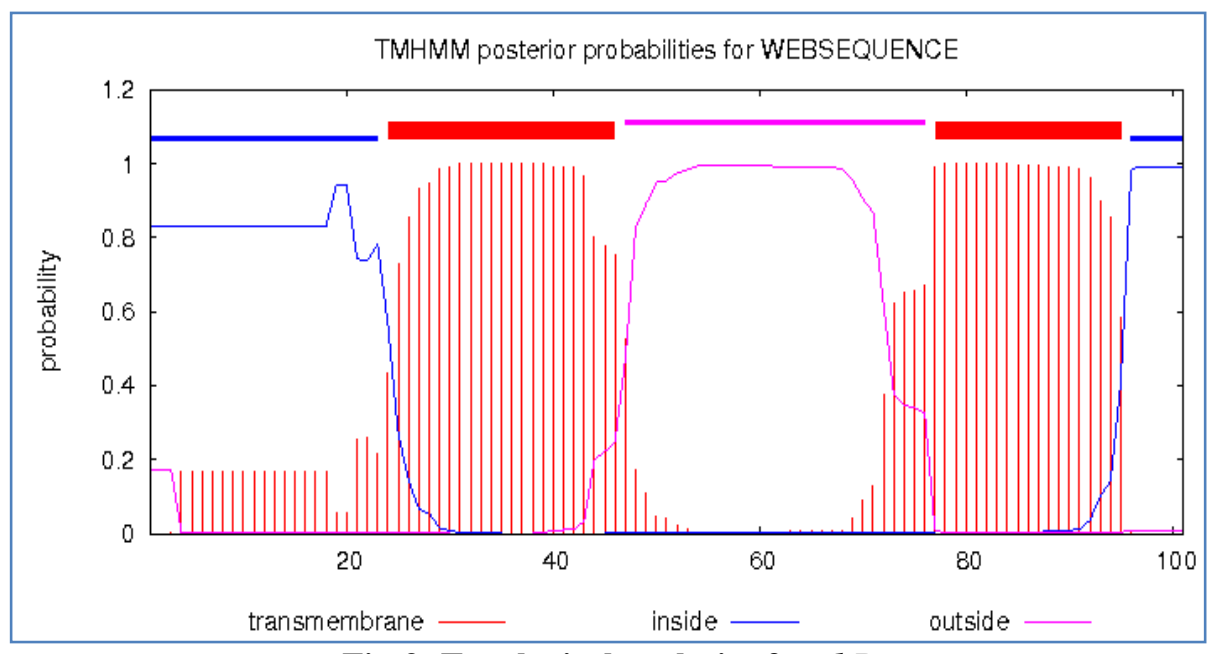

Fig-3: Topological analysis of $m n h B$ 


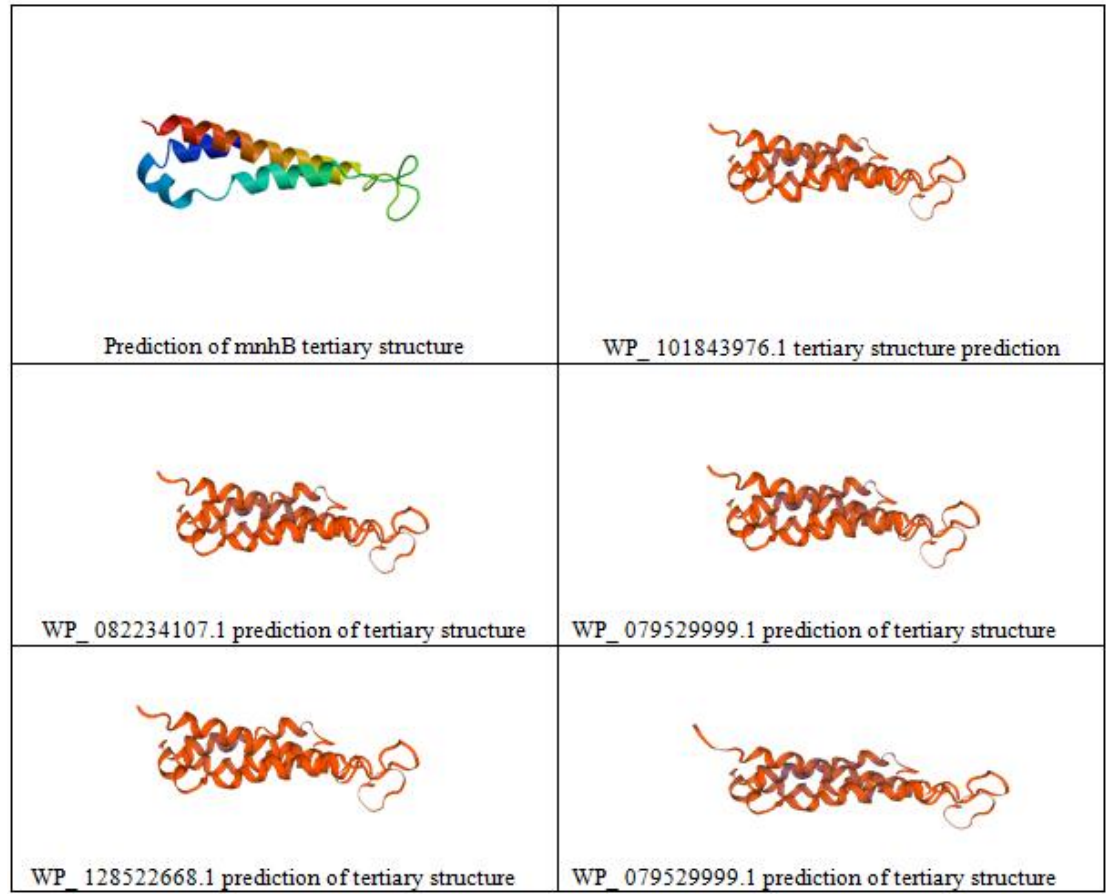

Fig-4: Three-dimensional structure prediction of $m n h B$ and its related protein

\section{Construction of $m n h B$ phylogenetic tree}

The phylogenetic tree of $m n h B$ was constructed by using the "neighbor joining" method selected by mega5.1 software [7] (Fig. 5). $\operatorname{mnhB}$ and $\mathrm{Na}^{+} / \mathrm{H}^{+}$retrotransporters on other protein $\beta$ subunits gathered together and formed an independent branch. It is speculated that $m n h B$ gene is probably a new member of $\mathrm{Na}^{+} / \mathrm{H}^{+}$retrotransporter gene family on $\beta$ subunit [8].

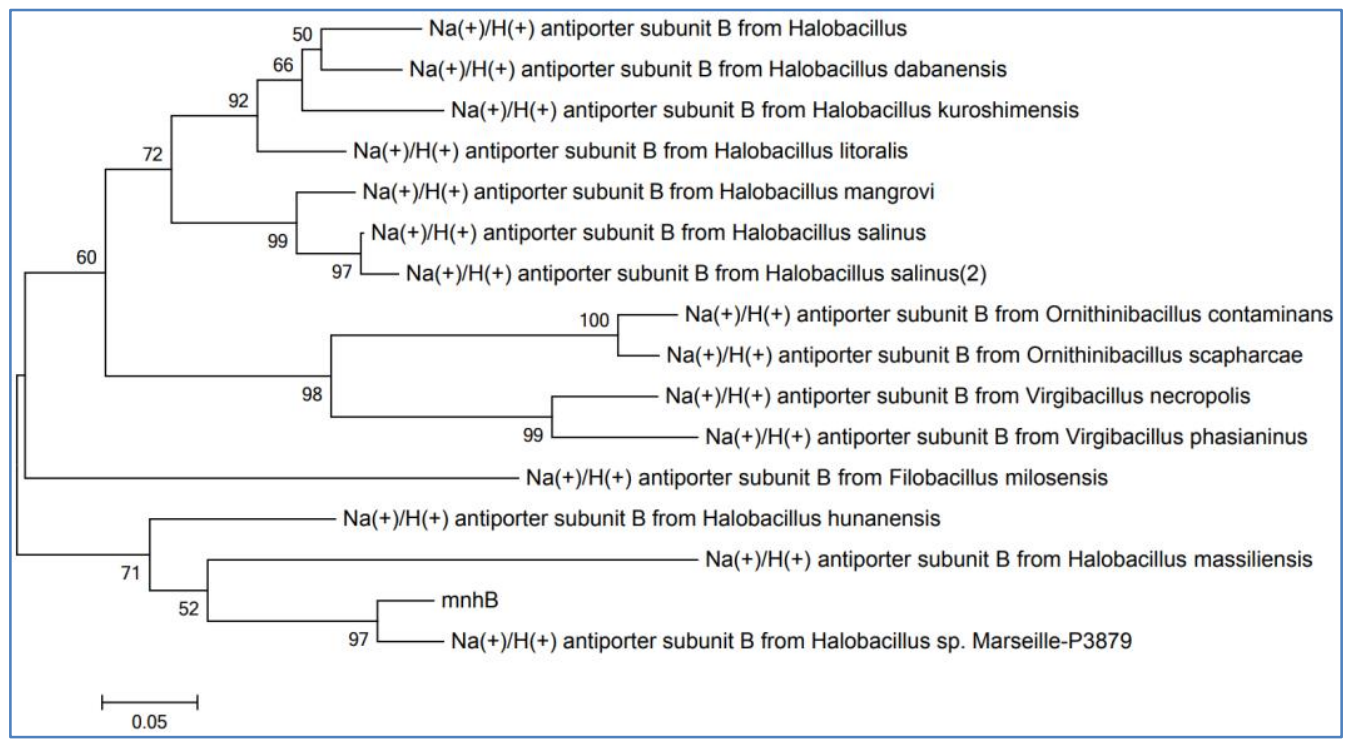

Fig-5: Neighbor-Joining phylogenetic tree of selected homologs of Ha_mnhB

\section{Activity determination}

The reverse membrane was prepared by high pressure cell crusher JG-1A of Ningbo Xinzhi Biotechnology Co., Ltd. and low temperature and high speed centrifuge and low temperature and high speed centrifuge of Hitachi CRG Series. In the AO fluorescence quenching method, Hitachi F-7000 fluorescence spectrophotometer of Hitachi Ltd was used to determine the protein activity of $m n h B$. All the above were carried out with reference to the literature. In the reaction system, the transport activity of $m n h B$ gene of Halobacillus $\mathrm{Y} 5$ to univalent positive ionons $\left(\mathrm{Na}^{+}, \mathrm{Li}^{+}\right.$, $\mathrm{K}^{+}$) was measured. Therefore, we believed that the transport activity of $m n h B$ for monovalent cations $\mathrm{Na}^{+}$, $\mathrm{Li}^{+}$and $\mathrm{K}^{+}$occurred but not those of /pUC18 (Fig.6). 
Wang Yongjie et al., Sch J Eng Tech, Apr, 2021; 9(4): 40-45

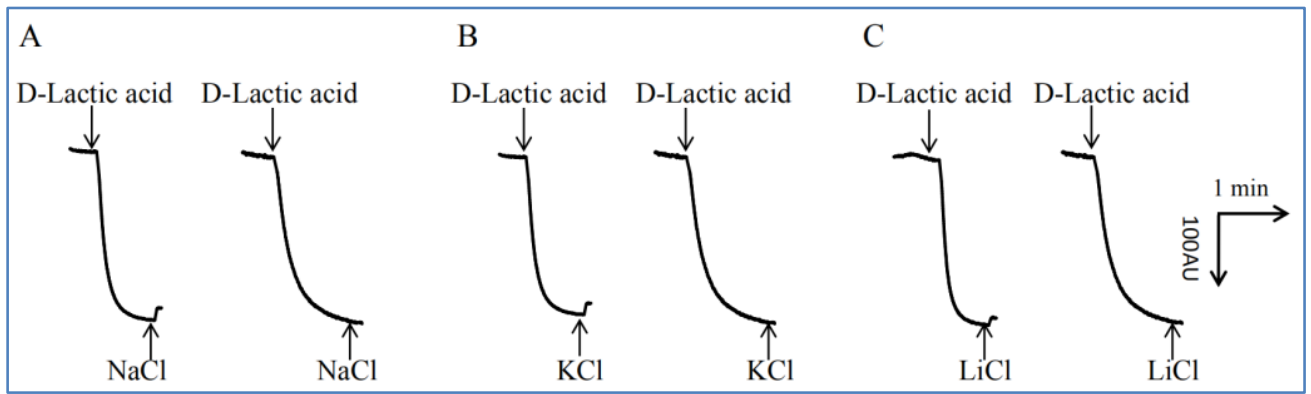

Fig-6: Assays for $\mathrm{Na}^{+}\left(\mathrm{Li}^{+}, \mathrm{K}^{+}\right) / \mathrm{H}^{+}$antiport activity of $m n h B$ protein

\section{CONCLUSION AND DISCUSSION}

Halobacillus is a Gram-positive moderately halophilic bacterium that can produce spores [9]. In prokaryotes,sodium/hydrogen antiporters play an important role in catalyzing the excretion of base cations such as $\mathrm{Na}^{+}, \mathrm{Li}^{+}$or $\mathrm{K}^{+}$in cells in exchange for external protons, so as to reduce the cytoplasmic concentration of toxic alkaline metal cations and maintain intracellular $\mathrm{pH}$ homeostasis $[10,11]$. At present, the $m n h B$ gene of bacillus halophilus has been preliminarily studied, but the $\mathrm{Na}^{+} / \mathrm{H}^{+}$reverse transport function of $m n h B$ gene has not been reported.

In this study, we first cloned $m n h B$ gene, and then transformed the ligation product into competent cells of E.coli KNabc by functional complementation method, which showed salt tolerance in high saline alkaline medium. Bioinformatics software was used to analyze the hydrophobicity and transmembrane structure of the protein. It was found that the protein was hydrophilic and had transmembrane structure. The $m n h B$ gene of Halobacillus Y5 and 5 sequences of Halobacillus sp. marseille-p3879, Halobacillus massiliensis [12], Halobacillus hunanensis [13], Halobacillus litoralis [14] and Halobacillus mangrovi [15] (accession No. WP 101843976.1、WP 082234107.1、WP_079529999.1、WP_ 128522668.1 、WP_ 085029880.1). The results showed that the three-dimensional structures of the six proteins were very similar, suggesting that $m n h B$ gene may have the function of sodium / hydrogen ion reverse transport. At the same time, DNA sequence homology analysis showed that the homology was $93 \%$. It is further confirmed that $m n h B$ gene is likely to be a new member of $\mathrm{Na}^{+} / \mathrm{H}^{+}$antiporter gene family on $\beta$ subunit [16]. In conclusion, using a large number of data from bioinformatics tools and bioinformatics database, and combined with the experimental data of this study, we put forward some guiding opinions on the $\mathrm{Na}^{+} / \mathrm{H}^{+}$ antiporter function of $m n h B$ gene, and laid a foundation for the further study of $\mathrm{Na}^{+} / \mathrm{H}^{+}$antiporter gene family.

\section{ACKNOWLEDGEMENTS}

This work was supported by Heilongjiang Bayi Agricultural University Support Program for San Heng San Zong (grant ZRCPY202028) and Heilongjiang Bayi Agricultural University Doctor's Research Foundation (XDB201822).

\section{REFERENCE}

1. Vreeland RH. Mechanisms of halotolerance in microorganisms. CRC Critical reviews in microbiology. 1987 Jan 1;14(4):311-56.

2. Yang L, Jiang J, Zhang B, Zhao B, Wang L, Yang SS. A primary sodium pump gene of the moderate halophile Halobacillus dabanensis exhibits secondary antiporter properties. Biochemical and biophysical research communications. 2006 Jul 28;346(2):612-7.

3. El Fakharany E, Hassan M. A universal method for extraction of genomic DNA from various microorganisms using lysozyme. New Biotechnology. 2016(33):S210.

4. Jiang J, Wang L, Zhang H, Wu H, Huang H, Yang L. Putative paired small multidrug resistance family proteins PsmrAB, the homolog of YvdSR, actually function as a novel two-component $\mathrm{Na}+\mathrm{H}+$ antiporter. FEMS microbiology letters. 2013 Jan 1;338(1):31-8.

5. ZhanG XY, Gao YN. PCR Primer design and software application skills [J]. Information biology. 2004, (04):15-18, 46. (in Chinese)

6. Wang YH, Liu YS, Shi DX, Zhu BG, LV BL, FU $\mathrm{SY}, \mathrm{XU} \mathrm{M}$, WANG W, YIN KD. Functional Identification of $\mathrm{Na}+\mathrm{H}+$ Antiporter in Novel YdjM Superfamily Members. China Biotechnology. 2019 Jan 10;38(12):32-40.

7. Som A, Fuellen G. The effect of heterotachy in multigene analysis using the neighbor joining method. Molecular phylogenetics and evolution. 2009 Sep 1;52(3):846-51.

8. Feki K, Brini F, Amar SB, Saibi W, Masmoudi K. Comparative functional analysis of two wheat $\mathrm{Na}+\mathrm{H}+$ antiporter SOS1 promoters in Arabidopsis thaliana under various stress conditions. Journal of applied genetics. $2015 \mathrm{Feb}$;56(1):15-26.

9. Liebgott PP, Casalot L, Paillard S, Lorquin J, Labat M. Marinobacter vinifirmus sp. nov., a moderately halophilic bacterium isolated from a wine-barreldecalcification wastewater. International journal of systematic and evolutionary microbiology. 2006 Nov 1;56(11):2511-6.

10. Padan E, Schuldiner S. Molecular physiology of $\mathrm{Na}+\mathrm{H}+$ antiporters, key transporters in circulation of $\mathrm{Na}+$ and $\mathrm{H}+$ in cells. Biochimica et Biophysica 
Acta (BBA)-Bioenergetics. 1994 Apr 28;1185(2):129-51.

11. Ito M, Guffanti AA, Oudega B, Krulwich TA. mrp, a Multigene, Multifunctional Locus inBacillus subtilis with Roles in Resistance to Cholate and to $\mathrm{Na}+$ and in $\mathrm{pH}$ Homeostasis. Journal of Bacteriology. 1999 Apr 15;181(8):2394-402.

12. Yang L, Zhang B, Wang L, Yang S. The short Cterminal hydrophilic domain of $\mathrm{NhaH} \mathrm{Na}+\mathrm{H}+$ antiporter from Halobacillus dabanensis with roles in resistance to salt and in $\mathrm{pH}$ sensing. Chinese Science Bulletin. 2008 Nov;53(21):3311-6.

13. Peng QZ, Peng QJ, Zhang YQ, Liu ZX, Wang YX, Li WJ, Cui XL, Chen YG. Halobacillus hunanensis sp. nov., a moderately halophilic bacterium isolated from a subterranean brine. Antonie Van Leeuwenhoek. 2009 Nov;96(4):497-504.
14. Yang L, Tan RX, Wang Q, Huang WY, Yin YX. Antifungal cyclopeptides from Halobacillus litoralis YS3106 of marine origin. Tetrahedron letters. 2002 Sep 9;43(37):6545-8.

15. Woo M, Park SH, Park K, Park MK, Kim JY, Lee HS, Sohn JH, Lee DW, Nam G, Shin KS, Lee SJ. Draft genome sequence of the halophilic Halobacillus mangrovi KTB 131 isolated from Topan salt of the Jeon-nam in Korea. Genomics data. 2017 Dec 1;14:18-20.

16. Yang L, Zhang B, Wang L, Yang S. The short Cterminal hydrophilic domain of $\mathrm{NhaH} \mathrm{Na}+\mathrm{H}+$ antiporter from Halobacillus dabanensis with roles in resistance to salt and in $\mathrm{pH}$ sensing. Chinese Science Bulletin. 2008 Nov;53(21):3311-6. 